\title{
Laboratory assessment of the efficiency of corrosion inhibitors at oilfield pipelines of the West Siberia region IV. Tests in a flow recirculation loop
}

\author{
I. S. Sivokon, ${ }^{1}$ Yu. B. Makarychev, ${ }^{2}$ Y. A. Kuzenkov ${ }^{2}$ and N. N. Andreev ${ }^{2}$ \\ ${ }^{1}$ OJSC Transenergostroi, Derbenevskaya nab. 7, bldg. 10, Moscow, \\ 115114 Russian Federation
}

${ }^{2}$ A. N. Frumkin Institute of Physical Chemistry and Electrochemistry, Russian Academy of Sciences, Leninskii pr. 31, Moscow, 119071 Russian Federation *E-mail: $\underline{\text { n.andreev@mail.ru }}$

\begin{abstract}
This article continues a series of publications dedicated to lab assessment of the efficiency of carbon dioxide corrosion inhibitors at oilfield pipelines of the West Siberia region. Results of the test in a flow recirculation loop are reviewed herein. The paper highlights the effect of temperature, test duration, oxygen concentration, condition of specimen surface, flow velocity, presence of hydrocarbon phase and inhibitor concentration on the corrosion rate and protective properties of a wide range of commercial inhibitors. The paper gives recommendations on specific conditions for testing inhibitors to assess their applicability for the protection of water lines, oil pipelines with low watercut and oil pipelines with high product watercut.
\end{abstract}

Key words: corrosion inhibitors, test methods, oilfield pipelines.

Received: May 28, 2013.

doi: $10.17675 / 2305-6894-2013-2-3-203-215$

The flow recirculation loop test is one of few methods for lab assessment of inhibitor efficiency that makes it possible to simulate oilfield pipelines of almost any type [1]. This can be achieved by generation of a fluid flow with hydrodynamic and thermochemical properties similar to the real environment of pipeline operation, from water pipelines to oil pipelines with water-containing products. In our point of view, such testing is a mandatory stage in inhibitor selection for their piloting in real pipelines.

The purpose of this paper is to assess the capability of this method in ranking of carbon-dioxide corrosion inhibitors and define the test conditions that precisely simulate the conditions of oilfield pipeline operation which are critical in terms of the failure rate.

Like in $[2,3]$, these tasks were addressed using commercial inhibitors as examples. At the same time, we have kept the previously accepted numeration. Inhibitors No. 3, 4 and 7 are qualified by the manufacturers as imidazolines and No. 5 as a quaternary ammonium base. No. 1 is a mixture of quaternary ammonium bases and imidazoline derivatives. Inhibitors No. 2 and 6 are amines. 


\section{Experimental procedure}

The test facility whose layout is given in Fig. 1 comprised a container with a thermostatting system, a test loop made of plastic pipes with cells for the specimens, a flow meter, a circulation water pump with valves, and a gas injection system. The corrosion rate $(K)$ of specimens made of grade 20 steel $(30 \times 40 \mathrm{~mm})$ was determined from the mass loss following exposure to the test fluids circulating in the facility at various velocities (from 1 to $6 \mathrm{mps})$.

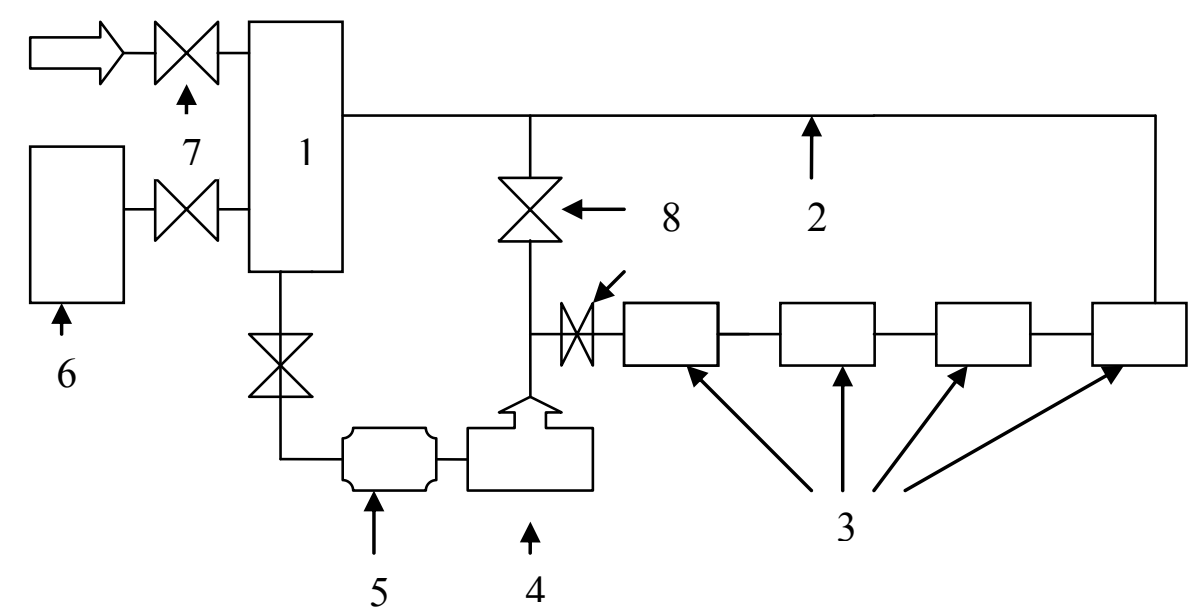

Fig. 1. Flow recirculation loop scheme. 1 , accumulation tank with a thermostatting system; 2 , test loop; 3, cells for the specimens; 4, fluid flow meter; 5, circulation water pump; 6 , saturator vessel for the preparation of model fluids; 7 , gas injection system; 8 , water valves.

A model water solution simulating the formation water at West Siberia fields and a two-phase model fluid on its basis were selected as the corrosive fluids. The make-up of these fluids and their preparation for the test are described in [2].

Before the tests, the circulation pump was turned on and the facility was first washed for 30 minutes with hot water $\left(50^{\circ} \mathrm{C}\right)$ and a detergent, then for 15 minutes with water at room temperature. After that, the water was drained off, the specimens were inserted into the cells, and the system was purged with an inert gas flow to remove $\mathrm{O}_{2}$.

The simulation fluids ( 25 liters) prepared for the tests were forced over by the inert gas flow into the test loop. After that, the pump was turned on to ensure liquid circulation inside the loop, and the thermostatting system was turned on as well. The test time was measured from the instant of the loop fill-in with the simulation fluid. Unless specified otherwise, the tests lasted for 24 hours and the $\mathrm{O}_{2}$ concentration in the model fluids was $2-2.5 \mathrm{mg} / \mathrm{l}$.

Preparation of steel specimens for the test, their post-test treatment, and estimation of $K$ values followed by calculation of the protection levels $(Z)$ were similar to those described in [2]. At least 3 parallel experiments were made in each fluid. 


\section{Results and discussion}

The effect of $\mathrm{O}_{2}$ concentration on $\mathrm{K}$ in uninhibited fluids can be demonstrated using of the model water fluid at $1 \mathrm{mps}$ flow rate as an example (Table 1). As $\mathrm{O}_{2}$ concentration increased, the $K$ values increased markedly for air-oxidized specimens. Thus, $K$ of steel at a temperature $(t)$ of $8^{\circ} \mathrm{C}$ increased almost 3 -fold, namely from 6.2 to $17.1 \mathrm{~g} \cdot \mathrm{m}^{-2} \cdot \mathrm{day}^{-1}$, with an increase in $\mathrm{O}_{2}$ concentration from $2.0-2.5$ to $3.0-3.5 \mathrm{mg} / \mathrm{l}$. At the same time, we did not manage to ensure a stricter control of $\mathrm{O}_{2}$ concentration in the lab facility or a deeper deaeration during a 24-hour test.

Table 1. $K$ values in uninhibited model fluids for various test conditions.

\begin{tabular}{|c|c|c|c|c|c|c|}
\hline Model fluid & $\begin{array}{c}\text { Test } \\
\text { time, h }\end{array}$ & $t,{ }^{\circ} \mathrm{C}$ & $\begin{array}{l}\text { Specimen } \\
\text { treatment }\end{array}$ & $\begin{array}{c}\text { Flow rate, } \\
\text { mps }\end{array}$ & $\begin{array}{c}\mathrm{O}_{2} \text { concentration, } \\
\mathrm{mg} / \mathrm{l}\end{array}$ & $\stackrel{K,}{\mathrm{~g} \cdot \mathrm{m}^{-2} \cdot \mathrm{day}^{-1}}$ \\
\hline Water solution & 24 & 8 & Oxid. & 1 & $2-2.5$ & 6.2 \\
\hline Same & 24 & 8 & Oxid. & 1 & $3-3.5$ & 17.1 \\
\hline Same & 6 & 8 & Oxid. & 1 & $2-2.5$ & 32.8 \\
\hline Same & 12 & 8 & Oxid. & 1 & $2-2.5$ & 21.0 \\
\hline Same & 24 & 8 & Oxid. & 1 & $2-2.5$ & 18.6 \\
\hline Same & 24 & 8 & Activ. & 1 & $2-2.5$ & 19.6 \\
\hline Same & 24 & 25 & Oxid. & 1 & $2-2.5$ & 32.4 \\
\hline Same & 24 & 25 & Activ. & 1 & $2-2.5$ & 32.8 \\
\hline Two-phase fluid & 24 & 8 & Oxid. & 1 & $2-2.5$ & 8.7 \\
\hline Same & 24 & 8 & Activ. & 1 & $2-2.5$ & 9.4 \\
\hline Same & 24 & 25 & Oxid. & 1 & $2-2.5$ & 26.8 \\
\hline Same & 24 & 25 & Activ. & 1 & $2-2.5$ & 28.1 \\
\hline Same & 24 & 45 & Oxid. & 1 & $2-2.5$ & 64.8 \\
\hline Same & 24 & 45 & Activ. & 1 & $2-2.5$ & 64.9 \\
\hline Same & 24 & 8 & Oxid. & 3 & $2-2.5$ & 15.4 \\
\hline Same & 24 & 8 & Activ. & 3 & $2-2.5$ & 17.0 \\
\hline Same & 24 & 8 & Oxid. & 6 & $2-2.5$ & 42.1 \\
\hline Same & 24 & 8 & Activ. & 6 & $2-2.5$ & 42.8 \\
\hline Same & 24 & 25 & Oxid. & 3 & $2-2.5$ & 83.6 \\
\hline Same & 24 & 25 & Oxid. & 6 & $2-2.5$ & 138.2 \\
\hline Same & 24 & 25 & Activ. & 6 & $2-2.5$ & 138.0 \\
\hline Same & 24 & 45 & Oxid. & 3 & $2-2.5$ & 104.6 \\
\hline Same & 24 & 45 & Activ. & 3 & $2-2.5$ & 104.0 \\
\hline Same & 24 & 45 & Oxid. & 6 & $2-2.5$ & 149.0 \\
\hline Same & 24 & 45 & Activ. & 6 & $2-2.5$ & 149.0 \\
\hline
\end{tabular}


The effect of the test duration on $K$ in uninhibited model fluids can be demonstrated using an experiment in the water solution at $t=8^{\circ} \mathrm{C}$ (Table 1). An increase in the test duration from 6 to 24 hours caused an almost two-fold decrease in $K$ for air-oxidized specimens (from 32.8 to $18.6 \mathrm{~g} \cdot \mathrm{m}^{-2} \cdot \mathrm{day}^{-1}$ ). In this case, the most significant $K$ decrease (from 32.8 to $21.0 \mathrm{~g} \cdot \mathrm{m}^{-2} \cdot$ day $^{-1}$ ) occurred in the time range of $6-12$ hours.

The effect of $t$ on $K$ in the uninhibited model solution and in a two-phase fluid was determined at a flow velocity of $1 \mathrm{mps}$ (Table 1). As $t$ increased, the $K$ value increased in all the tests. In corrosion tests simulating operational conditions of water lines (model water solution), a $t$ growth from 8 to $25^{\circ} \mathrm{C}$ increased $K$ from 17.1 to 32.4 and from 19.6 to $32.8 \mathrm{~g} \cdot \mathrm{m}^{-2} \cdot$ day $^{-1}$ for air-oxidized and acid-activated specimens, respectively.

In the two-phase model fluid, a similar $t$ increase changed the $K$ value from 8.7 to $26.8 \mathrm{~g} \cdot \mathrm{m}^{-2} \cdot$ day $^{-1}$ for air-oxidized steel and from 9.4 to $28.1 \mathrm{~g} \cdot \mathrm{m}^{-2} \cdot$ day $^{-1}$ for activated steel. Heating of the model fluid by additional $20^{\circ} \mathrm{C}$ intensified corrosion as well. The corrosion rate increased more than twofold for both types of specimens.

The effect of flow velocity on the $K$ value was studied for the two-phase model fluid as an example. With a growth in flow velocity, $K$ also increased (Table 1). For air-oxidized specimens at $t=8^{\circ} \mathrm{C}$ and a flow rate of $1 \mathrm{mps}, K=8.7 \mathrm{~g} \cdot \mathrm{m}^{-2} \cdot$ day $^{-1}$. At $3 \mathrm{mps}$, this value increased almost twice to become $15.4 \mathrm{~g} \cdot \mathrm{m}^{-2} \cdot \mathrm{day}^{-1}$. A flow velocity increase to $6 \mathrm{mps}$ boosted $K$ to $42.1 \mathrm{~g} \cdot \mathrm{m}^{-2} \cdot$ day $^{-1}$. Similar regularities were also noted for activated specimens. At a temperature $t=8^{\circ} \mathrm{C}$, the $K$ values were $9.4 \mathrm{~g} \cdot \mathrm{m}^{-2} \cdot$ day $^{-1}$ at $1 \mathrm{mps}$ flow velocity; $17.0 \mathrm{~g} \cdot \mathrm{m}^{-2} \cdot \mathrm{day}^{-1}$ at $3 \mathrm{mps}$; and $42.8 \mathrm{~g} \cdot \mathrm{m}^{-2} \cdot \mathrm{day}^{-1}$ at $6 \mathrm{mps}$. Similar dependences were observed at a higher $t$ values.

The effect of specimen activation on $K$ in uninhibited model fluids is not strong, probably because the test conditions are characterized by relatively high $K$ values. At the same time, differences in $K$ values for air-oxidized and activated specimens in 24-hour tests did not exceed the test error (Table 1).

The effect of a hydrocarbon phase on $K$ in uninhibited model fluids was estimated at $5 \%$ of hydrocarbons (white spirit) and various $t$ values (Table 1). Comparison of $K$ values estimated under similar conditions in the model water solution and two-phase fluid indicated some inhibition of corrosion by hydrocarbons.

The effect of test duration on the $Z$ of inhibitors was studied for inhibitors No. 2 and 4 as examples in model water solution with air-oxidized specimens at $t=25^{\circ} \mathrm{C}$ and $25 \mathrm{mg} / 1$ inhibitor concentration $\left(C_{\text {in }}\right)$. It was found that $Z$ values increased for the first $6-8$ hours of the test until an adsorption film of the inhibitor was generated. Further $Z$ changes in time are comparable to the test error.

The effect of $C_{\text {in }}$ on inhibitor protective effect was tested in both model fluids at various $t$ and flow rates. In all cases, inhibitor addition reduced the $K$ of steel. With an increase in $C_{\text {in }}$, the protective effect increased in all tests.

The effect of specimen activation on $Z$ of the inhibitors was within the experimental error in all cases. This is well illustrated by the results of the tests with inhibitor No. 1 
(Table 2). Therefore, only data obtained with air-oxidized specimens were used in further analysis of the test results.

Table 2. Protective capacity of inhibitor No. 1 under various test conditions.

\begin{tabular}{|c|c|c|c|c|c|}
\hline Model fluid & $\begin{array}{l}C_{\mathrm{in}}, \\
\mathrm{mg} / \mathrm{l}\end{array}$ & $t,{ }^{\circ} \mathbf{C}$ & $\begin{array}{c}\text { Specimen } \\
\text { preparation }\end{array}$ & Flow rate, mps & $Z, \%$ \\
\hline Water solution & 25 & 8 & Oxid. & 1 & 68 \\
\hline Same & 25 & 8 & Activ. & 1 & 73 \\
\hline Same & 50 & 8 & Oxid. & 1 & 91 \\
\hline Same & 50 & 8 & Activ. & 1 & 84 \\
\hline Same & 25 & 25 & Oxid. & 1 & 32 \\
\hline Same & 25 & 25 & Activ. & 1 & 32 \\
\hline Same & 50 & 25 & Oxid. & 1 & 66 \\
\hline Same & 50 & 25 & Activ. & 1 & 64 \\
\hline Two-phase fluid & 50 & 8 & Oxid. & 1 & 61 \\
\hline Same & 50 & 8 & Activ. & 1 & 63 \\
\hline Same & 100 & 8 & Oxid. & 1 & 96 \\
\hline Same & 100 & 8 & Activ. & 1 & 91 \\
\hline Same & 50 & 25 & Oxid. & 1 & 70 \\
\hline Same & 50 & 25 & Activ. & 1 & 76 \\
\hline Same & 100 & 25 & Oxid. & 1 & 92 \\
\hline Same & 100 & 25 & Activ. & 1 & 98 \\
\hline Same & 50 & 45 & Oxid. & 1 & 73 \\
\hline Same & 50 & 45 & Activ. & 1 & 73 \\
\hline Same & 100 & 8 & Oxid. & 3 & 91 \\
\hline Same & 100 & 8 & Activ. & 3 & 89 \\
\hline Same & 100 & 25 & Oxid. & 3 & 80 \\
\hline Same & 100 & 25 & Activ. & 3 & 83 \\
\hline Same & 100 & 45 & Oxid. & 3 & 73 \\
\hline Same & 100 & 45 & Activ. & 3 & 73 \\
\hline Same & 100 & 8 & Oxid. & 6 & 74 \\
\hline Same & 100 & 8 & Activ. & 6 & 73 \\
\hline Same & 100 & 25 & Oxid. & 6 & 64 \\
\hline Same & 100 & 25 & Activ. & 6 & 65 \\
\hline Same & 50 & 45 & Oxid. & 6 & 45 \\
\hline Same & 50 & 45 & Activ. & 6 & 45 \\
\hline
\end{tabular}


With an increase in flow velocity in the two-phase model fluid, the $Z$ value of the inhibitors decreased in all the $t$ range studies (Fig. 2).

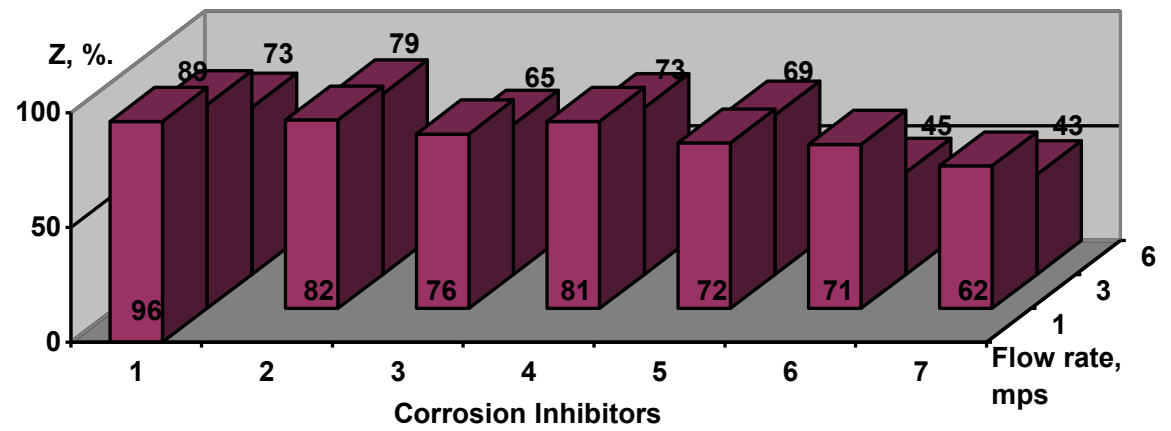

$a$

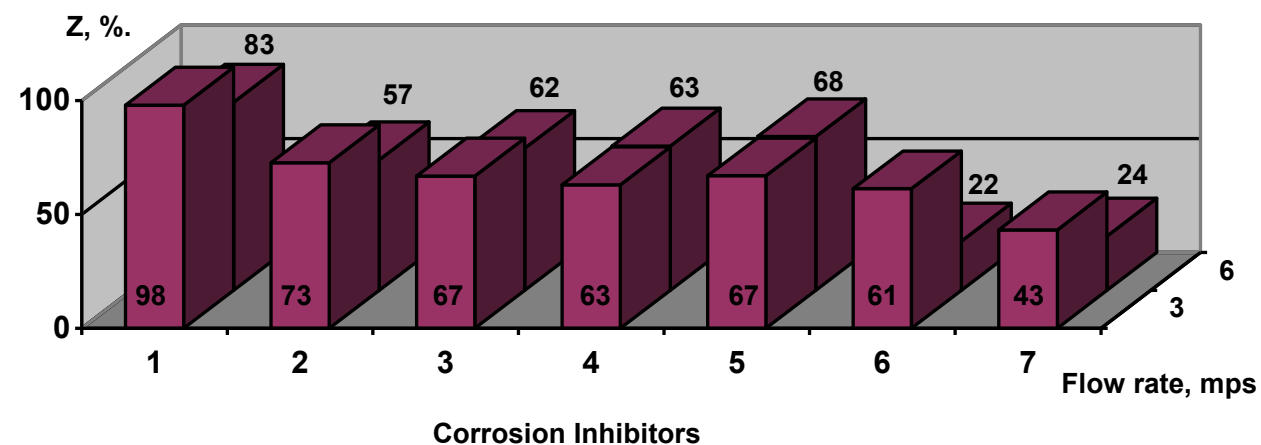

$b$

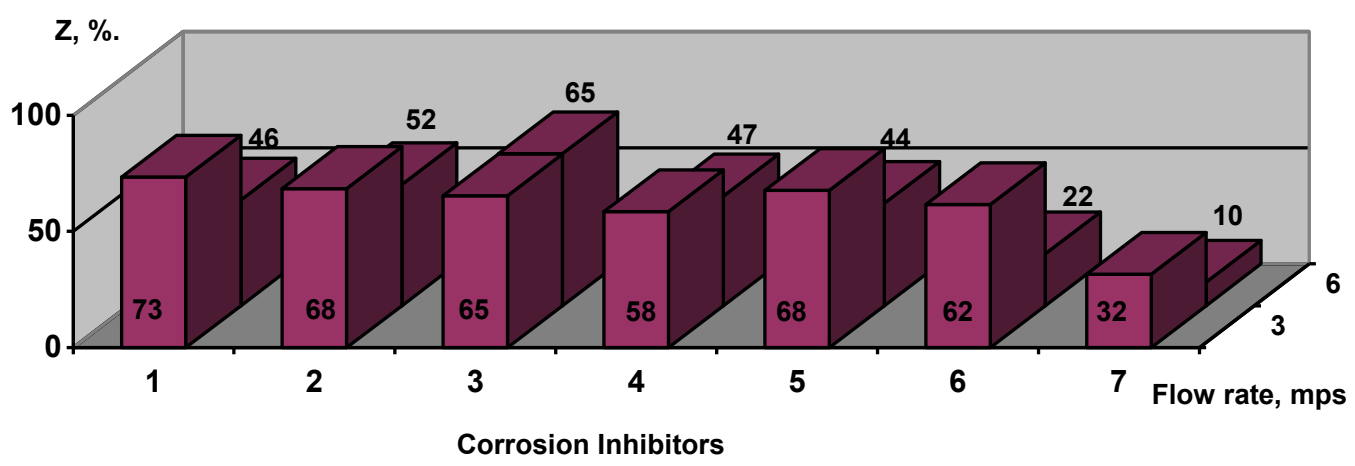

$c$

Fig. 2. Effect of flow rate on the $Z$ of inhibitors $(100 \mathrm{mg} / \mathrm{l})$ for air-oxidized specimens in a two-phase model fluid at a temperature of $8(a), 25(b)$ and $45^{\circ} \mathrm{C}(c)$.

The effect of temperature on the $Z$ value is nearly the same for water and waterorganic model environments: with a temperature increase, $Z$ decreases slightly (Fig. 3, 4). This regularity was demonstrated for the entire tested range of $C_{\text {in }}$ and flow rates. Deviations are rare and do not exceed the measurement error. 


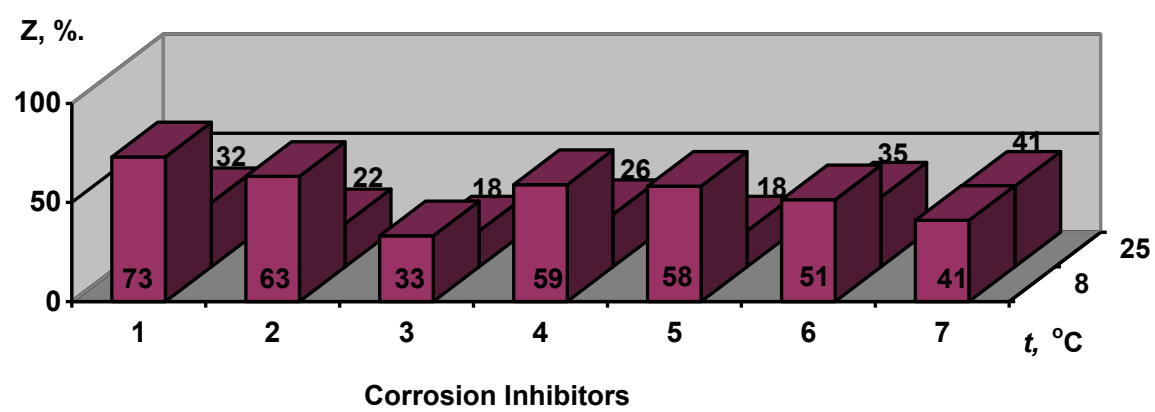

$a$

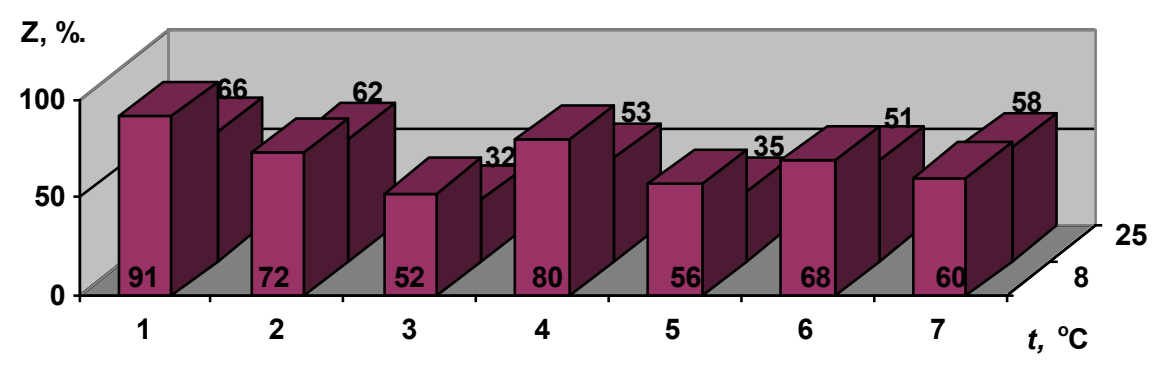

Corrosion Inhibitors

$b$

Fig. 3. Effect of $t$ on the $Z$ of inhibitors $(a, 25 \mathrm{mg} / 1 ; b, 50 \mathrm{mg} / 1$ for air-oxidized specimens in model water solution at $1 \mathrm{mps}$ flow rate.

The effect of oxygen concentration on the protective effect was tested using chemical No. 1 and air-oxidized specimens in model water solution at $t=8,25$ and $45^{\circ} \mathrm{C}$. With an increase in oxygen concentration, $Z$ decreased slightly (Fig. 5, 6). In fact, upon an $\mathrm{O}_{2}$ concentration change from $2.0-2.5$ to $3.0-3.5 \mathrm{mg} / \mathrm{l}$, the $Z$ value dropped from 94.5 to $91.2 \%$ at $5^{\circ} \mathrm{C}$, from 74.6 to $65.9 \%$ at $25^{\circ} \mathrm{C}$, and from 62.3 to $58.6 \%$ at $45^{\circ} \mathrm{C}$. A similar decrease in $Z$ values was observed in the two-phase model fluid at $25^{\circ} \mathrm{C}$ and a $6 \mathrm{mps}$ flow rate.

The hydrocarbon phase effect on $Z$ value of the inhibitors was studied in both model fluids. In all cases, it manifested itself as an increase in the protective effect (Fig. 7, 8).

The ranking of the inhibitors based on tests simulating the operation of water lines (model water solution) was mainly studied at $t=25^{\circ} \mathrm{C}$. This is because the $K$ value increases and $Z$ values do not increase with an increase in $t$ in the tests of this type. Therefore, the protective capability of the inhibitors should not affect the protection of water pipelines at low $t$. The failure rate of the pipelines is determined by the operation mode and the sections with elevated temperatures $(t)$.

At $C_{\text {in }}=25 \mathrm{mg} / \mathrm{l}$, none of the inhibitors provided $Z>41 \%$. For the air-oxidized specimens, the best three inhibitors in terms of protective capacity make up the following series:

No. $7(41 \%)>$ No. $6(35 \%)>$ No. $1(32 \%)$. 


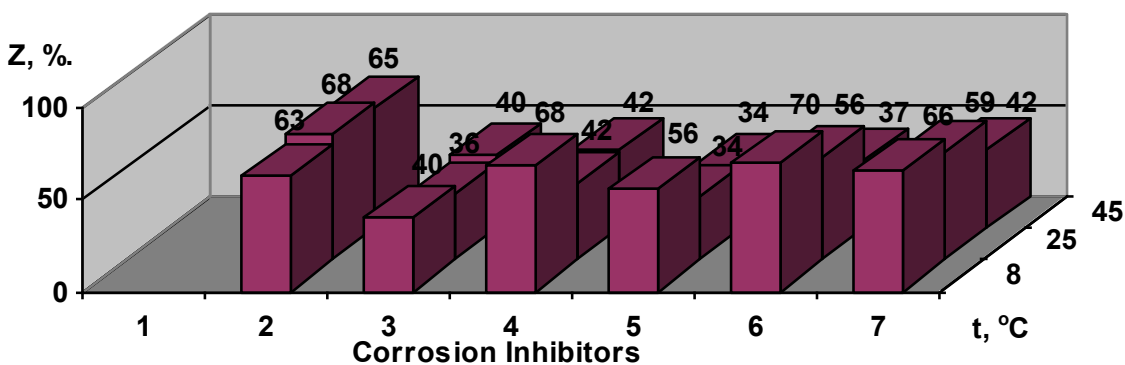

$a$

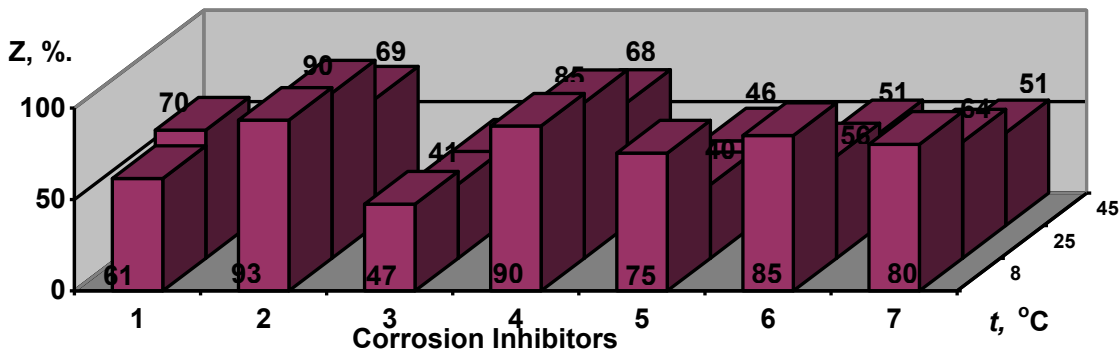

$b$

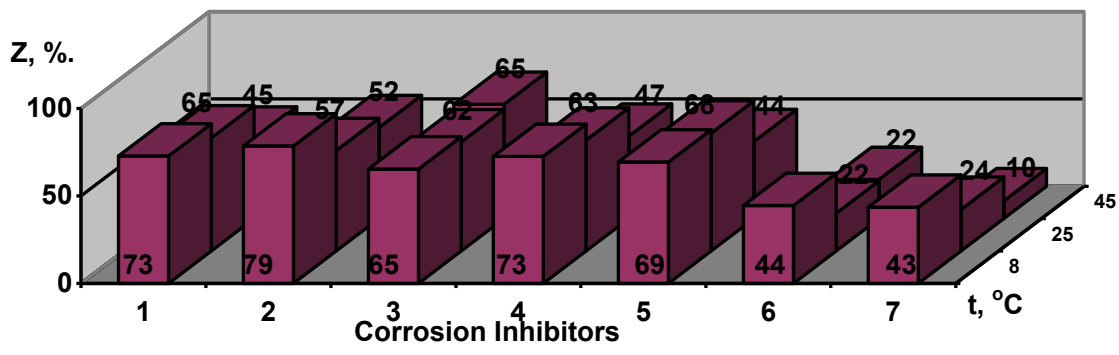

$c$

Fig. 4. Effect of $t$ on the $Z$ of inhibitors $(a, 25 \mathrm{mg} / 1 ; b, 50 \mathrm{mg} / 1 ; c, 100 \mathrm{mg} / 1)$ for air-oxidized specimens in two-phase model fluid at $1 \mathrm{mps}(a, b)$ and $6 \mathrm{mps}(c)$ flow rate.

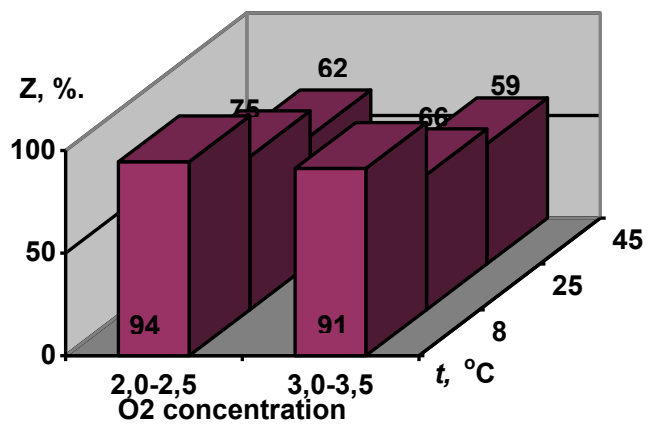

Fig. 5. Effect of $\mathrm{O}_{2}$ concentration on the protective effect of inhibitor No. 1 for air-oxidized specimens in the model electrolyte at 8,25 and $45^{\circ} \mathrm{C}$ and $1 \mathrm{mps}$ flow rate. 


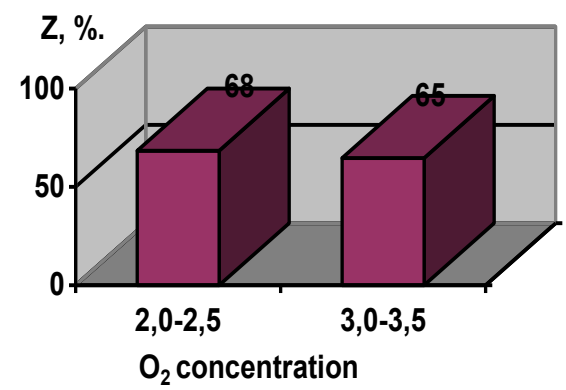

Fig. 6. Effect of oxygen concentration on the protective effect of inhibitor No. 1 for airoxidized specimens in the two-phase model fluid at $25^{\circ} \mathrm{C}$ and $6 \mathrm{mps}$ flow rate.

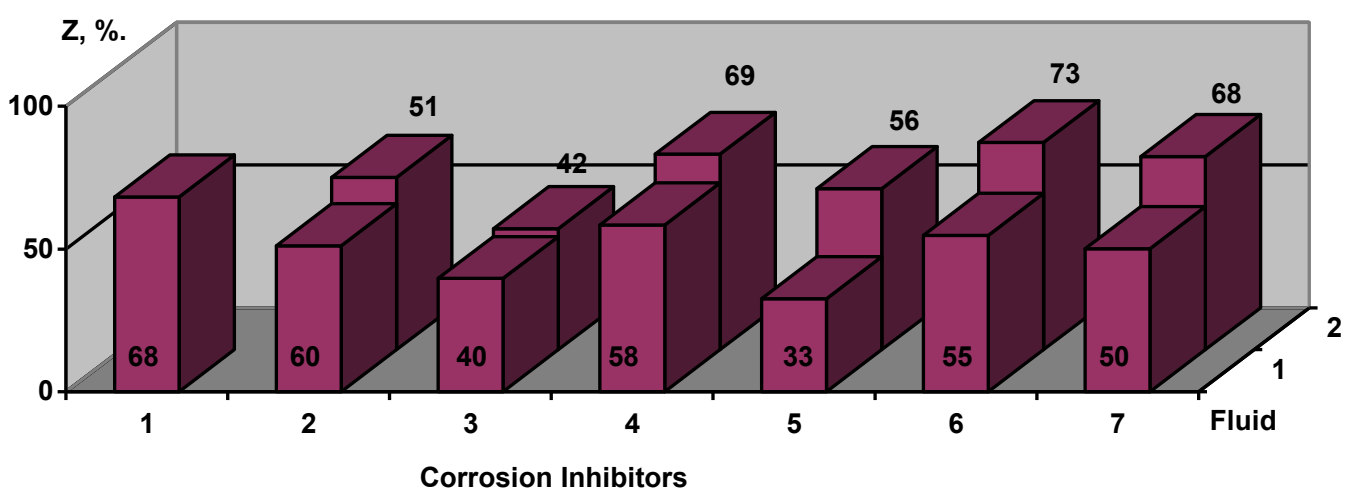

$a$

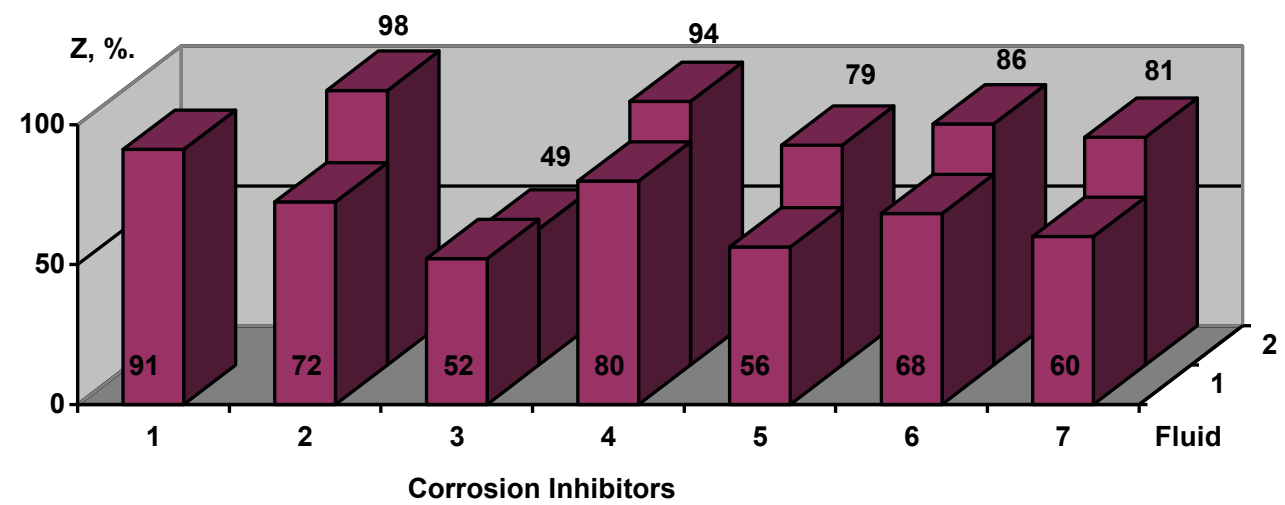

$a$

Fig. 7. Protective effect of inhibitors $(a, 25 \mathrm{mg} / \mathrm{l} ; b, 50 \mathrm{mg} / \mathrm{l})$ in the model water solution (fluid 1) and two-phase fluid (fluid 2) at $5^{\circ} \mathrm{C}$ for air-oxidized specimens at 1 mps flow rate. 


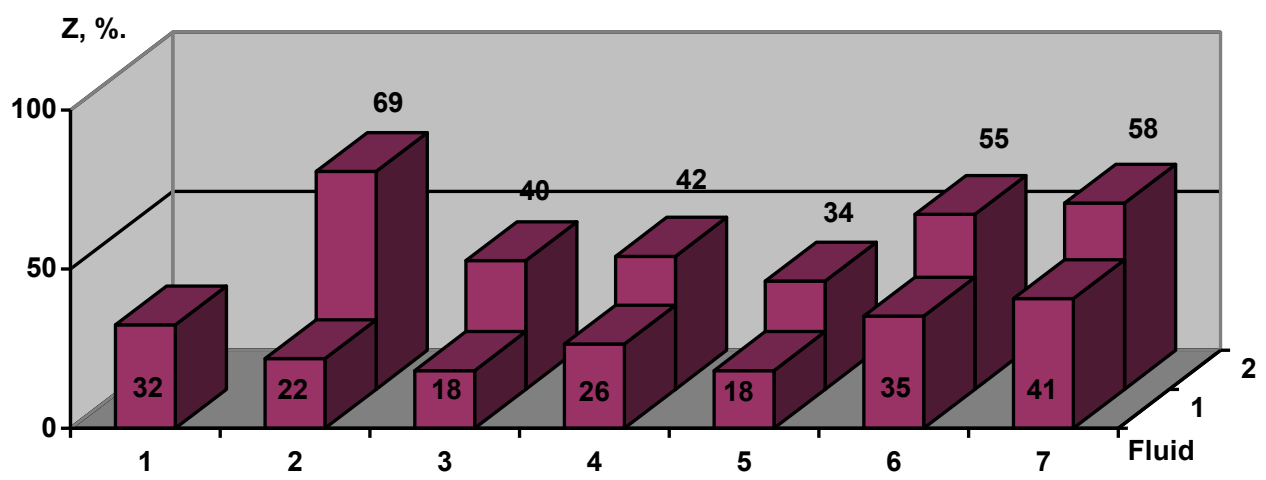

Corrosion Inhibitors

$a$

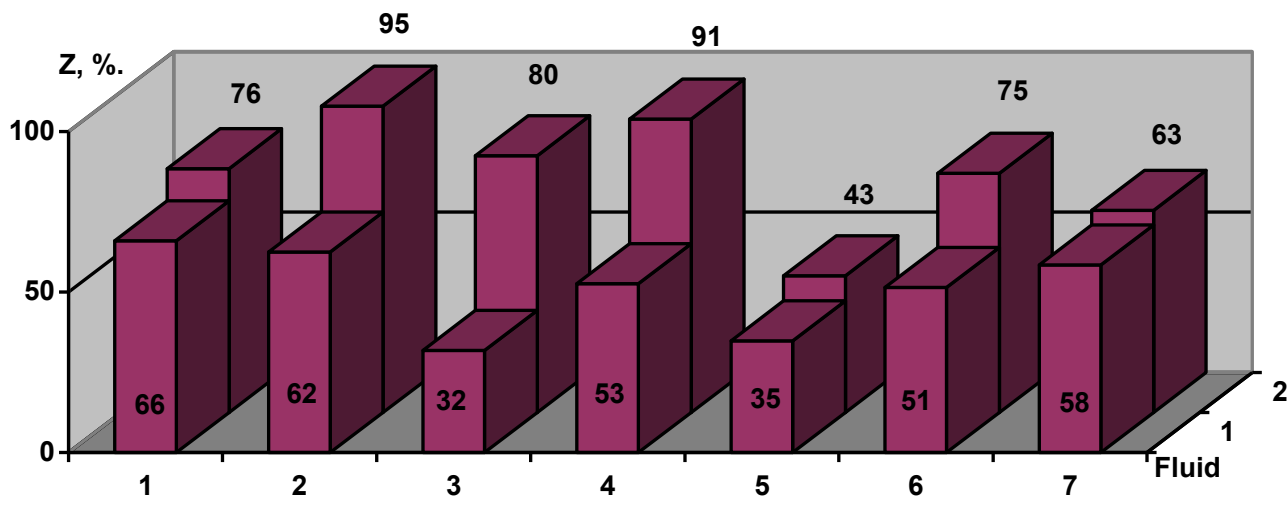

Corrosion Inhibitors

$b$

Fig. 8. Protective effect of inhibitors $(a, 25 \mathrm{mg} / 1 ; b, 50 \mathrm{mg} / \mathrm{l})$ in the model water solution (fluid 1) and two-phase fluid (fluid 2) at $25^{\circ} \mathrm{C}$ for air-oxidized specimens at $1 \mathrm{mps}$ flow rate.

The worst performance under these conditions was demonstrated by inhibitors No. 3 and No. 5 (both 18\%) (Fig. 9).

Under the same conditions but at $C_{\mathrm{in}}=50 \mathrm{mg} / 1$, the best inhibitors ranged as follows:

No. $1(66 \%)>$ No. $2(62 \%)>$ No. $7(58 \%)$.

The worst results were delivered by chemical No.3 (32\%). Inhibitors No.7 and 1 are common for both "top lists".

Due to similar reasons, the key focus of the ranking of inhibitors under conditions simulating the operation of oil pipelines with small watercut (two-phase model fluid) was made on the data obtained at high $t=45^{\circ} \mathrm{C}$. In our point of view, it is these conditions that determine the failure rate of pipelines of this type. In this case, the "top list" of inhibitors at $25 \mathrm{mg} / 1$ with air-oxidized specimens was as follows (Fig. 10):

No. $1(76 \%)>$ No. $2(68 \%)>$ No. $7(46 \%)$. 
The worst results were delivered by inhibitors No. 5 and 6 .
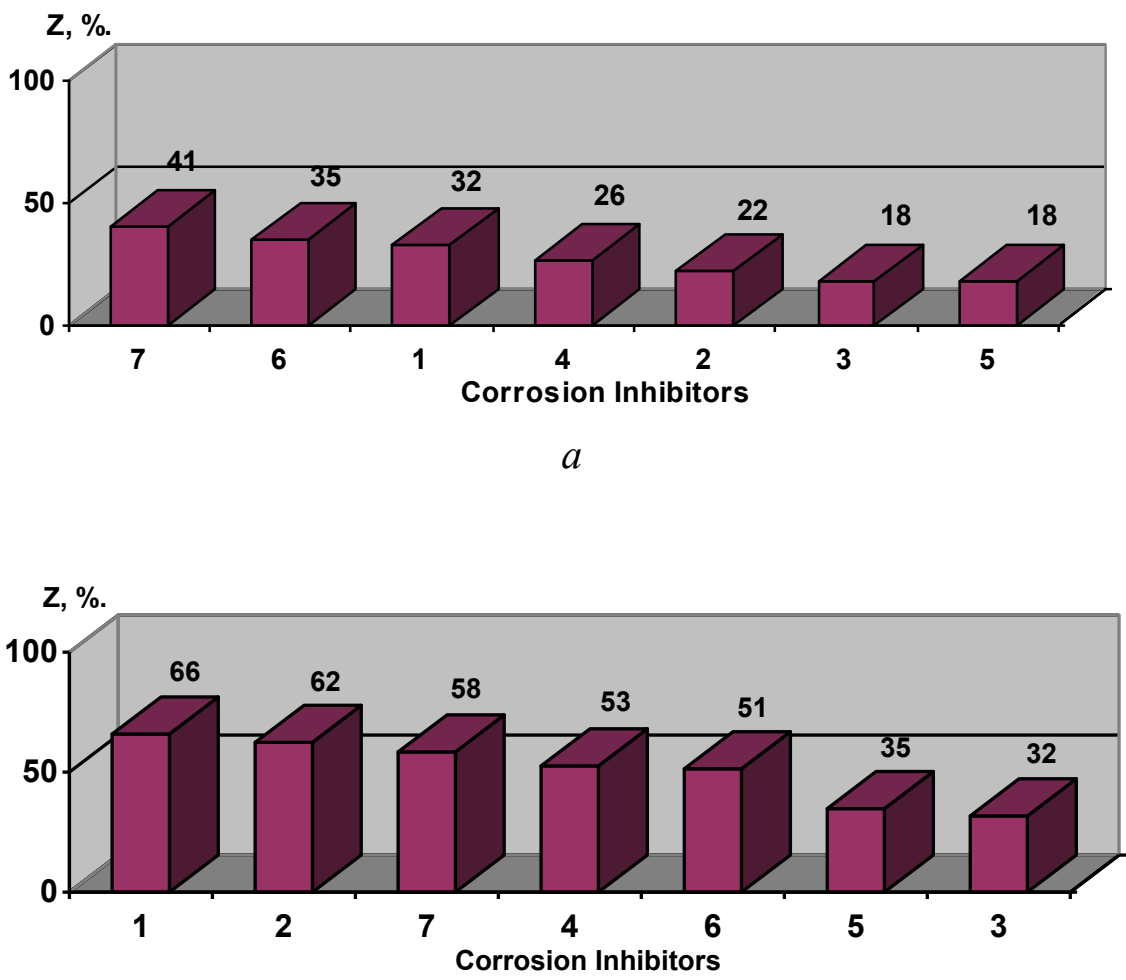

$b$

Fig. 9. Protective effect of inhibitors $(a, 25 \mathrm{mg} / 1 ; b, 50 \mathrm{mg} / \mathrm{l})$ in the model water solution at $25^{\circ} \mathrm{C}$ for air-oxidized specimens at $1 \mathrm{mps}$ flow rate.

For $C_{\text {in }}=50 \mathrm{mg} / \mathrm{l}$, the following sequence was identified (Fig. 10):

No. $1(78 \%)>$ No. $2(75 \%)>$ No. $4(69 \%)$.

The worst results were delivered by chemicals No.3 and 6. Inhibitors No. 1 and 2 are common for both lists.

The test-based ranking of the inhibitors simulating operation of oil pipelines with high watercut (two-phase model fluid) was performed at $t=45^{\circ} \mathrm{C}, 6 \mathrm{mps}$ flow velocity and $C_{\mathrm{in}}=$ $100 \mathrm{mg} / \mathrm{l}$. In this case, the "top list" of inhibitors was as follows (Fig. 11):

No. $4(65 \%)>$ No. $2(52 \%)>$ No. $4(47 \%)$.

The worst results were demonstrated by chemicals No. 7 and 6 . 


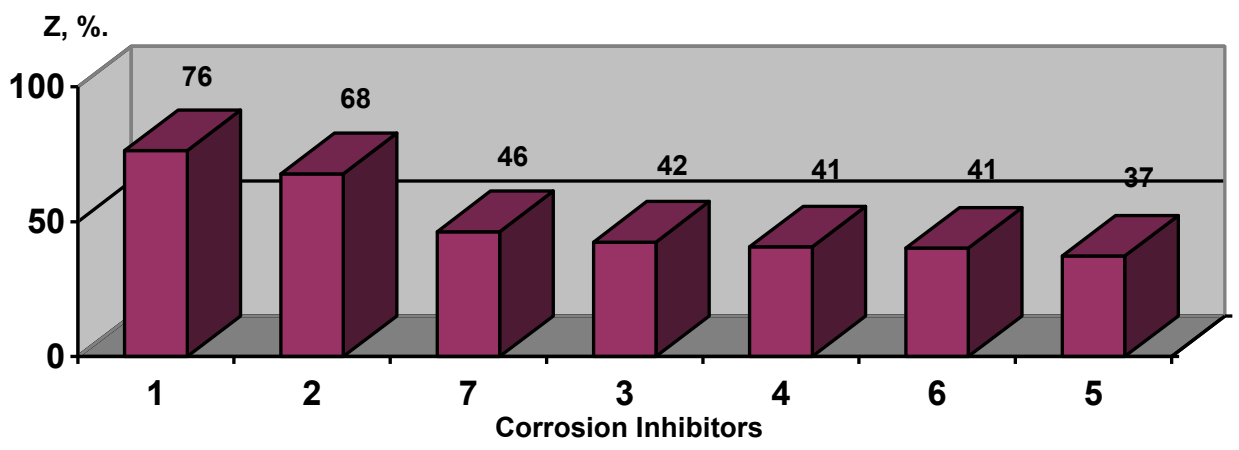

$a$

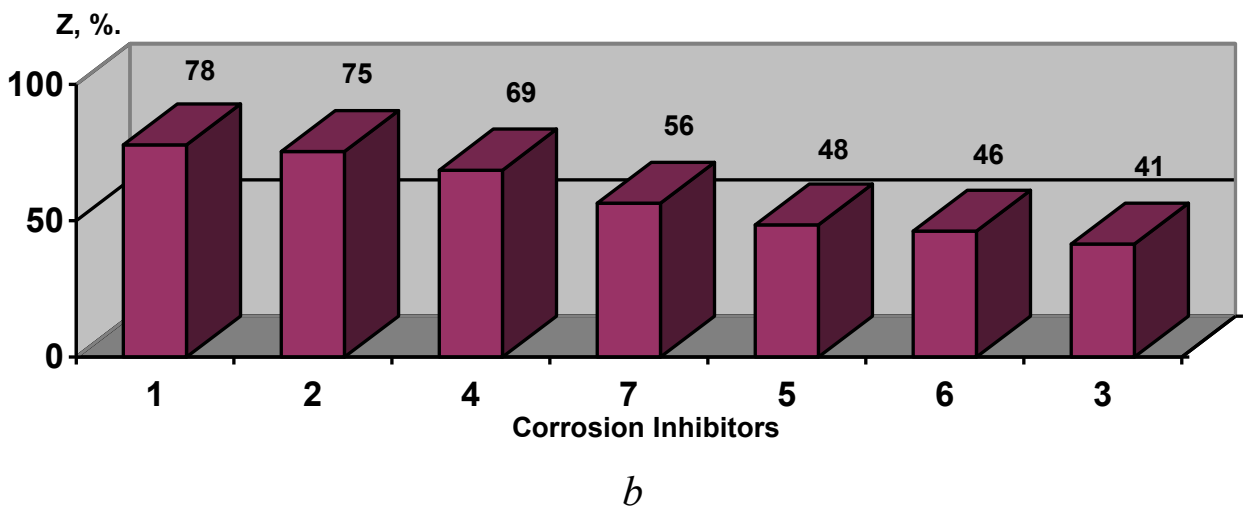

Fig. 10. Protective effect of inhibitors $(a, 25 \mathrm{mg} / \mathrm{l} ; b, 50 \mathrm{mg} / \mathrm{l})$ in the two-phase model fluid at $45^{\circ} \mathrm{C}$ for air-oxidized specimens at $1 \mathrm{mps}$ flow rate.

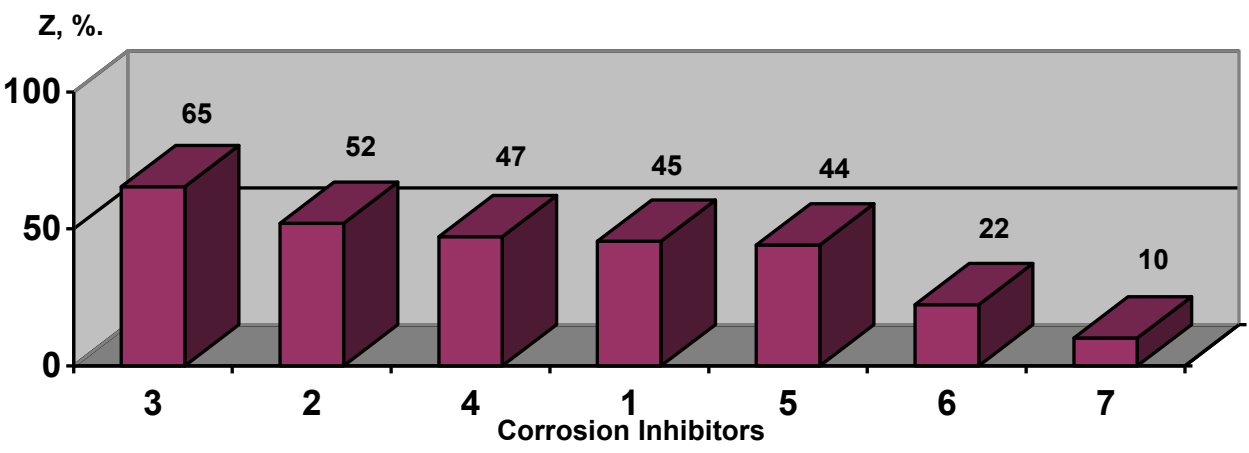

Fig. 11. Protective effect of inhibitors $(100 \mathrm{mg} / \mathrm{l})$ in the two-phase model fluid at $45^{\circ} \mathrm{C}$ for airoxidized specimens at $6 \mathrm{mps}$ flow rate. 


\section{Conclusions}

1. Tests should be carried out at the highest temperatures that occur at the pipelines being simulated. The inhibitor efficiency at low temperatures should not significantly affect the protection of pipelines.

2. The test duration in a recirculation loop should exceed 12 hours.

3. The $K$ and $Z$ values are similar for air-oxidized and activated specimens. This justifies a less sophisticated treatment of specimens that does not require acid etching.

4. Recirculation loop tests make it possible to recommend inhibitors No. 7 and 1 for the protection of water lines, No. 1 and 2 for oil pipelines with low watercut, and No. 3, 2, and 4 for oil pipelines with high watercut.

\section{References}

1. I. S. Sivokon and N. N. Andreev, Int. J. Corros. Scale Inhib., 2012, 1, no. 1, 65. doi: 10.17675/2305-6894-2012-1-1-065-079

2. I. S. Sivokon, D. B. Vershok and N. N. Andreev, Int. J. Corros. Scale Inhib., 2012, 1, no. 2, 130. doi: $10.17675 / 2305-6894-2012-1-2-130-145$

3. N. N. Andreev, N. G. Anufriev and I. S. Sivokon, Int. J. Corros. Scale Inhib., 2013, 2, no. 1, 17. doi: $10.17675 / 2305-6894-2013-2-1-017-029$ 